\title{
Atrazine-induced elevation or attenuation of the LH surge in the ovariectomized, estrogen-primed female rat: role of adrenal progesterone
}

\author{
Jerome M Goldman, Lori K Davis ${ }^{\dagger}$, Ashley S Murr and Ralph L Cooper \\ Endocrine Toxicology Branch, MD72, Toxicity Assessment Division, National Health and Environmental Effects \\ Research Laboratory, Office of Research and Development, US Environmental Protection Agency, \\ Research Triangle Park, North Carolina 27711, USA \\ Correspondence should be addressed to J M Goldman; Email: goldman.jerome@epa.gov
}

${ }^{\dagger}$ L K Davis is now at Impact Pharmaceutical Services, Research Triangle Park, North Carolina 27709, USA

\begin{abstract}
Multiple exposures to the herbicide atrazine (ATRZ) were shown to suppress the LH surge in both cycling female rats and those ovariectomized (OVX) and primed with estradiol $\left(E_{2}\right)$. A single ATRZ administration was found to induce a prompt and marked increase in progesterone $\left(P_{4}\right)$. As exogenous $P_{4}$ is known to have a differential effect on the LH surge depending on its temporal relationship with the surge, it was hypothesized that a single treatment in an OVX, $E_{2}$-primed rat would augment the surge, whereas several exposures would cause a decrease. Following four daily treatments with $100 \mathrm{mg} / \mathrm{kg}$, LH surge was suppressed. In contrast, a single ATRZ exposure elevated the surge. Two treatments were without effect. The single administration caused a large increase in $\mathrm{P}_{4}$ at 30 and 60 min that was likely attributable to adrenal secretion. Four exposures also elevated $\mathbf{P}_{\mathbf{4}}$ after the final treatment, although the duration of the increase was shortened. A single treatment with $0,10,30$, and $100 \mathrm{mg} / \mathrm{kg}$ ATRZ showed similar elevations at the highest concentration in $P_{4}$, the LH peak, and area under the curve (AUC), whereas four exposures reduced the AUC. An increase at $1 \mathrm{~h}$ in the expression of Kiss 1 in the anteroventral periventricular nucleus suggests that this regional kisspeptin neuronal population has a role in the ATRZ augmentation of the surge. These data support the hypothesis that ATRZ-induced changes in adrenal $\mathbf{P}_{4}$ can either augment or attenuate the surge depending on the temporal proximity of exposure to the rise in LH.
\end{abstract}

Reproduction (2013) 146 305-314

\section{Introduction}

The herbicide atrazine (ATRZ) (chloro-s-triazine), first introduced commercially in 1958, has become one of the most heavily used pesticides in the United States. It is designated as a restricted use pesticide for agriculture and is principally employed for corn, sorghum, and sugarcane to control pre- and post-emergent broadleaf and grassy weeds. In plants, ATRZ's principal mode of action has been determined to be an inhibition of chloroplast photosynthesis (Gysin \& Knuesli 1960).

A series of studies in rodents has shown that ATRZ is able to alter reproductive endocrine endpoints in both males and females. A downregulation of Leydig cell steroidogenic gene expression (Pogrmic et al. 2009) and reductions in testosterone concentrations have been observed both in serum and in testicular interstitial fluid following 3-4 weeks of exposure (Trentacoste et al. 2001, Friedmann 2002), although decreases in body weight with longer treatments were believed to contribute to these endocrine effects. In females, lifetime dietary exposures to ATRZ were found to cause premature reproductive senescence in female Sprague Dawley rats (Wetzel et al. 1994). Exposure by oral gavage for 3 weeks also reported to alter ovarian function in young-adult Sprague Dawley and Long-Evans females (Cooper et al. 1996). Subsequent studies in the young-adult females revealed that ATRZ suppresses the amplitude of the surge of $\mathrm{LH}$ in the ovariectomized (OVX), estradiol $\left(\mathrm{E}_{2}\right)$-primed female rat (Cooper et al. 2000, McMullin et al. 2004, Foradori et al. 2009) as well the ovulatory surge of LH in the intact proestrus female (Cooper et al. 2007). The ovulatory surge of $\mathrm{LH}$ represents the hormonal signal that triggers the final stages of ovarian follicular and oocytic maturation, and the ATRZ-induced disruption of gonadotropin secretion contributes to the altered ovarian cycling noted in the earlier studies. This attenuation in the LH surge is apparently due to an impact on the hypothalamic mechanisms underlying the secretion of $\mathrm{GnRH}$ and not via a direct effect on pituitary LH secretion (Cooper et al. 2000). However, the 
entirety of the toxicity pathway involved in this effect remains unknown.

A number of additional chlorotriazine studies have shown that ATRZ or its metabolites will stimulate the secretion of both $E_{2}$ and progesterone $\left(\mathrm{P}_{4}\right)$, in addition to inducing an increase in adrenal corticosterone. The increase in $E_{2}$ was primarily reported from in vitro studies (Sanderson et al. 2000, Pogrmic-Majkic et al. 2010, Tinfo et al. 2011), although a few publications with rodents have reported either marginal effects on aromatase activity or small statistically significant elevations in circulating $\mathrm{E}_{2}$ (Rivest et al. 2010, VictorCosta et al. 2010). In contrast, $\mathrm{P}_{4}$ and corticosterone have been found to rapidly increase in response to single or multiple oral exposures of ATRZ or its metabolites (Fraites et al. 2009, Taketa et al. 2011). In female rats, there is a marked elevation in both steroids within $15 \mathrm{~min}$ following a single exposure (Fraites et al. 2009, Laws et al. 2009). Such changes in circulating $E_{2}, P_{4}$, and corticosterone are known to feed back to the hypothalamus and pituitary and have an impact on the $\mathrm{LH}$ surge. In this regard, $\mathrm{E}_{2}$ and $\mathrm{P}_{4}$ serve complementary roles in initiating the surge, with each having a different temporal relationship with the rise in LH (e.g. Mahesh \& Muldoon 1987). During the normal rat estrus cycle, circulating concentrations of $\mathrm{E}_{2}$ rise during diestrus II and peak around mid-day on proestrus. This leads to an upregulation of the participant mechanisms of GnRH secretion, a contribution that is essential to the initiation of an LH surge. Around the time of the surge, $\mathrm{P}_{4}$ provides a synergistic complement to $E_{2}$, augmenting $\mathrm{LH}$ concentrations many-fold above levels induced by $E_{2}$ alone. However, if $\mathrm{P}_{4}$ is elevated over a period of days preceding the surge, even for brief periods as in the case of chlorotriazine exposure, it will have a negative influence on the central mechanisms that control LH and impair the surge (e.g. Caligaris et al. 1971, DePaolo \& Barraclough 1979).

$\mathrm{P}_{4}$ is a secretory product of both the ovaries and the adrenals, and this study was designed to examine the temporal relationship between an ATRZ-induced increase in adrenal $\mathrm{P}_{4}$ and the generation of the surge, using an OVX, $\mathrm{E}_{2}$-primed rat model. In contrast to the many studies demonstrating that 3 days of ATRZ exposure is able to impair the estrogen-induced release of LH (Cooper et al. 2000), it is hypothesized that a single oral exposure to ATRZ given to such females on the day of the anticipated estrogen-induced surge will promptly increase circulating $\mathrm{P}_{4}$ and enhance the amplitude of the LH surge. In contrast, daily ATRZ treatments administered over multiple days will cause a more extended exposure to $\mathrm{P}_{4}$ and attenuate the surge, as previously observed.

One family of neuropeptides that has emerged as a major upstream regulatory factor for $\mathrm{GnRH}$ secretion is the kisspeptins. Kisspeptin (Kiss1) neurons in the hypothalamic anteroventral periventricular nucleus
(AVPV) send fibers to $\mathrm{GnRH}$ neurons, and it has become apparent that this input serves as a powerful impetus for elicitation of the LH surge (e.g. Gottsch et al. 2004, Navarro et al. 2005). This study examined the relationship between the expression of Kiss1 mRNA in the AVPV and the surge following 1 and 4 days of ATRZ exposure.

\section{Materials and methods}

\section{Animals}

Long-Evans hooded female rats ( $\sim 60$ days old) were purchased from Charles River Laboratories (Raleigh, NC, USA). Each rat was housed individually in a clear polycarbonate cage $(20 \times 25 \times 47 \mathrm{~cm})$ with heat-treated pine shavings and provided PMI LabDiet Formulab 5008 and filtered tap water ad libitum. The housing rooms were maintained at $20-22{ }^{\circ} \mathrm{C}$ and $45-55 \%$ relative humidity under a $14 \mathrm{~h}$ light:10 $\mathrm{h}$ darkness photoperiod (lights on $0500 \mathrm{~h}$ ).

All animal care, handling, and treatment procedures conformed to NIH standards for laboratory animal research and were approved by the Institutional Animal Care and Use Committee at the National Health and Environmental Effects Research Laboratory.

\section{Chemicals}

ATRZ (97.1\% purity) was generously provided by Syngenta Crop Protection, Inc. (Greensboro, NC, USA). Dosing solutions were prepared as suspensions in 1\% methylcellulose (Sigma Chemical Co.) in reverse-osmosis purified water. The treatment regimens are described below.

\section{Experiment 1: single ATRZ concentration}

This experiment was designed to evaluate the effect of a single dosage of ATRZ administered on the day of the expected LH surge in the OVX, $E_{2}$-primed female rat compared with multiple exposures to the herbicide. Previous experiments had demonstrated that ATRZ at $100 \mathrm{mg} / \mathrm{kg}$ was able to suppress the $\mathrm{LH}$ surge following three daily treatments (Cooper et al. 2000). Consequently, this dose was initially employed to evaluate the temporal influence of the herbicide on the $\mathrm{LH}$ surge in OVX, $E_{2}$-primed female rats. This animal model, using OVX rats implanted with $E_{2}$-containing capsules, has been shown, under controlled $\mathrm{E}_{2}$ concentrations, to display daily $\mathrm{LH}$ surges over the course of 6 or 7 days (Legan \& Karsch 1975, Legan et al. 1975).

After a period of acclimation, vaginal lavages from each female were taken daily for at least 2 weeks to assess cycling status, as described elsewhere in detail (Goldman et al. 2007). Only those animals having at least two consecutive 4- or 5-day estrus cycles were used in experiments. These animals were deeply anesthetized under ketamine:xylazine anesthesia (70:10 mg/kg), bilaterally OVX, and implanted subcutaneously in the right flank with a $6 \mathrm{~mm}$ Silastic tubing capsule $(1.57 \mathrm{~mm}$ $\mathrm{ID} \times 3.18 \mathrm{~mm}$ OD) containing $\mathrm{E}_{2}$ benzoate (Sigma; $4 \mathrm{mg} / \mathrm{ml}$ in sesame oil), as described previously (Goldman et al. 2008). 

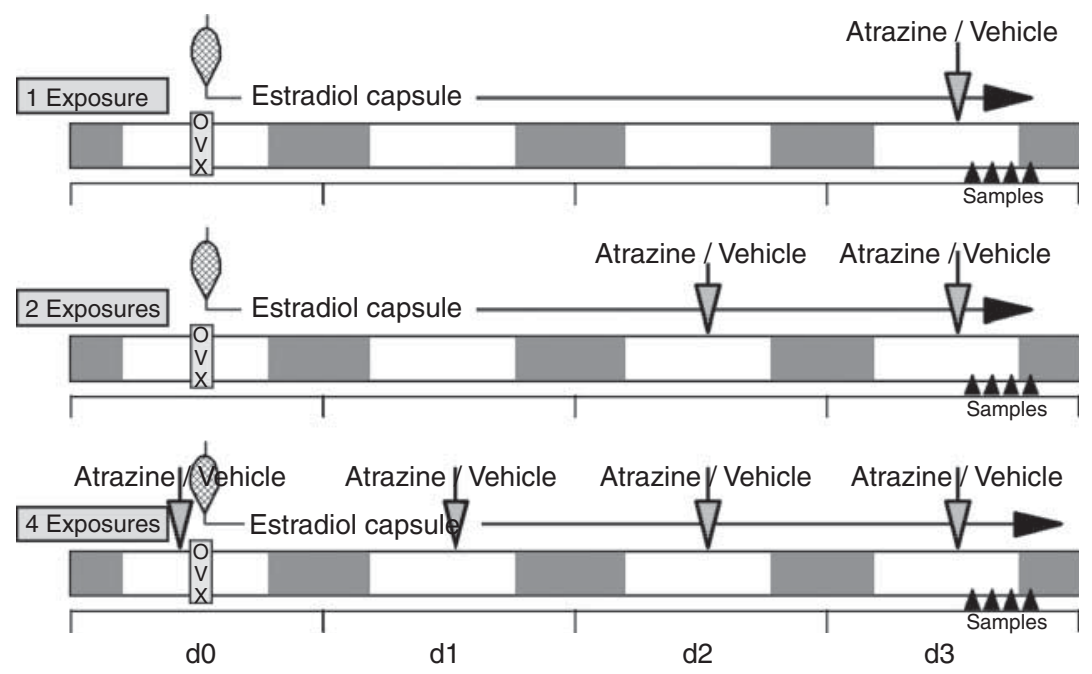

Figure 1 Study design for Experiment 1. Animals are OVX and implanted with an $\mathrm{E}_{2}$ capsule (hatched arrow) on day $0(\mathrm{~d} 0), 3$ days prior to sampling for blood by tail nick. Dosing is indicated for one, two, or four daily exposures at $1300 \mathrm{~h}$ by a shaded arrow, and blood samplings (1400, 1600, 1800, and $2000 \mathrm{~h}$ ) are shown by the small black triangles. The light and dark portions of the $14 \mathrm{~h}$ light: $10 \mathrm{~h}$ darkness photoperiod over the 4 days are represented by respective white and shaded blocks.
Capsules were soaked in saline prior to implantation to preclude an initial uneven rise in circulating $E_{2}$ concentrations before values fell to a relatively constant level.

One, two, or four daily treatments of $100 \mathrm{mg} / \mathrm{kg}$ ATRZ and the vehicle controls were administered at $1300 \mathrm{~h}$ by oral gavage ( $5 \mathrm{ml} / \mathrm{kg}$ body weight) prior to blood samples being taken. For animals receiving four exposures, the first day of ATRZ treatment preceded OVX by no more than $1 \frac{1}{2} \mathrm{~h}$ prior to surgery. This dosing time is within the critical window for the generation of the neural signals triggering the $\mathrm{LH}$ surge (Everett \& Sawyer 1950, Greig \& Weisz 1973). Three days after surgery, serial blood samples were taken for all animals at 1400, 1600, 1800 , and $2000 \mathrm{~h}$ in order to encompass the peak in the $\mathrm{LH}$ surge, which typically occurs between 1600 and $1800 \mathrm{~h}$. For the first three samples, $\sim 250 \mu$ l aliquots of blood were gently expressed from a nick in a lateral tail vein into small serum separation tubes. The animals were then killed by decapitation at $2000 \mathrm{~h}$ and trunk blood collected. This experimental paradigm is shown in Fig. 1. After each collection, blood was centrifuged at $1160 \mathrm{~g}\left(4^{\circ} \mathrm{C}\right)$ for $30 \mathrm{~min}$ and serum collected and frozen $\left(-60{ }^{\circ} \mathrm{C}\right)$ in siliconized centrifuge tubes for later analysis of serum $\mathrm{LH}$.

In order to assess ATRZ-related elevations in $\mathrm{P}_{4}$ that are present prior to the $1400 \mathrm{~h}$ sampling, a number of additional females were killed 30 and 60 min after a single or the last of four daily treatments. Trunk blood was collected and serum separated and frozen for $\mathrm{P}_{4}$ immunoassay.

\section{Experiment 2: dose-response assessments}

In order to determine whether the effects of ATRZ on the $\mathrm{LH}$ surge are dose responsive in nature, OVX, $\mathrm{E}_{2}$-primed animals were gavaged daily with $0,10,30$, or $100 \mathrm{mg} / \mathrm{kg}$ ATRZ for 1 or 4 days. The surgical procedure, dosing regimen, and serial blood sampling for $\mathrm{LH}$ were as described for Experiment 1. Additional females from each 1- and 4-day group were killed by decapitation at $1 \mathrm{~h}$ after dosing for determinations of serum $\mathrm{P}_{4}$.

\section{Experiment 3: Kiss1 genetic expression}

For the genetic expression of the kisspeptin (Kiss1) gene, additional OVX, $E_{2}$-primed Long-Evans hooded females were gavaged daily $(1300 \mathrm{~h}$ ) as before for 1 or 4 days with 0 or $100 \mathrm{mg} / \mathrm{kg}$ ATRZ and killed by decapitation at $1400 \mathrm{~h}$. Brains were promptly removed, frozen, and sectioned $(800 \mu \mathrm{m})$. AVPV punches were taken with a previously chilled 18-gauge stainless steel tube (1 $\mathrm{mm}$ diameter), expelled, and immediately snap frozen using dry ice. Brain punches from Long-Evans adult females (pooled female AVPVs) and males (pooled male cerebellar tissue) were used as positive and negative controls respectively.

RNA was extracted in TriReagent (Molecular Research Ctr, Cincinnati, OH, USA) following the manufacturer's instructions. RNA (25 ng/ $\mu \mathrm{l})$ was reverse transcribed using a qScript cDNA synthesis kit (Quanta BioSciences, Gaithersburg, MD, USA). In addition, a water sample was taken through the cDNA synthesis reaction to test for non-specific amplification and

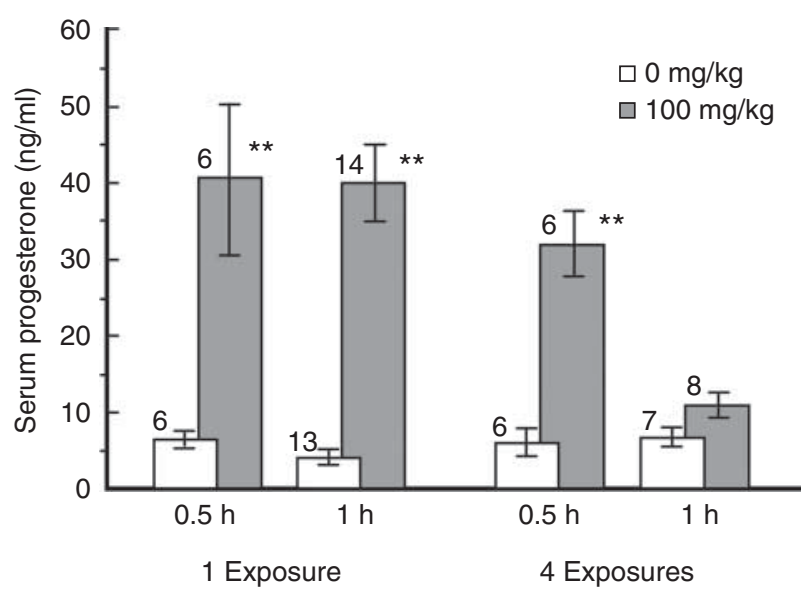

Figure 2 The effect of 0 or $100 \mathrm{mg} / \mathrm{kg}$ ATRZ on serum concentrations of $\mathrm{P}_{4}(\mathrm{ng} / \mathrm{ml} \pm$ s.E.M. at $30 \mathrm{~min}$ and $1 \mathrm{~h}$ after a single or fourth daily treatment). Numbers listed above each column indicate group sizes. ${ }^{* *} P<0.01$ for comparisons to $0 \mathrm{mg} / \mathrm{kg}$ groups. 
reagent contamination. Kiss1 primer (accession no. Rn00710914_m1) along with a $\beta$-actin housekeeping primer (Rn00667869_m1) for normalization were obtained from Applied Biosystems. Quantitation by RT-PCR was performed using TaqMan Gene Expression Assays from Applied Biosystems. $20 \times$ primer/probe mixture and $2 \times$ Taqman Mastermix were combined with molecular grade water and the cDNA. Each reaction was $10 \mu \mathrm{l}$ in a 384-well PCR plate (Applied Biosystems). In addition to cDNA samples, water was added as 'no template controls' to duplicate wells for each gene. Each plate was run on the Applied Biosystems $7900 \mathrm{HT}$ real-time PCR machine in the sequence $95^{\circ} \mathrm{C}$ for $10 \mathrm{~min}$ followed by 40 cycles at $95^{\circ} \mathrm{C}$ for $15 \mathrm{~s}$ and $60^{\circ} \mathrm{C}$ for $1 \mathrm{~min}$.

\section{Hormone assays}

In both experiments, sera from all time points were analyzed for $\mathrm{LH}$ to determine dose-related effects on the surge peak as well as the area under the curve (AUC). Serum concentrations of $E_{2}, P_{4}$, and $\mathrm{LH}$ were determined by RIA. $E_{2}$ and $P_{4}$ Coat-aCount RIA kits were purchased from Siemens Healthcare Diagnostics (Deerfield, IL, USA) and run according to the manufacturer's protocols. Analytical sensitivities were $8 \mathrm{pg} / \mathrm{ml}$ and $0.02 \mathrm{ng} / \mathrm{ml}$ respectively for the $E_{2}$ and $P_{4}$ assays. Steroid intra- and inter-assay coefficients of variation (CV) were $<10 \%$. The LH RIA was performed using materials provided by Dr A Parlow from the National Hormone and Pituitary Program (Harbor-UCLA Medical Center, Torrance, CA, USA). Individual tracers were radiolabeled with ${ }^{125}$ I (PerkinElmer NEN Radiochemicals, Waltham, MA, USA) using chloramine-T and labeled hormone was separated from free iodide by gel filtration chromatography. Iodination parameters, reference, and antibody dilutions were carried out according to recommendations accompanying each kit, and all RIAs used goat anti-rabbit gamma-globulin (Calbiochem/EMD Chemicals, Gibbstown, NJ, USA) as secondary antibody. A 24-h co-incubation $\left(4^{\circ} \mathrm{C}\right)$ of sample and primary antibody prior to the addition of labeled hormone for an additional $24 \mathrm{~h}$ increased the assay sensitivity to $0.11 \mathrm{ng} / \mathrm{ml}$. All samples were run in duplicate, and the intra- and inter-assay $\mathrm{CV}$ were $<12 \%$.

\section{Statistical analysis}

Serial LH samples for both Experiments 1 and 2 were analyzed by a repeated measures ANOVA (SAS 9.1, Cary, NC, USA). Because the time of appearance of a surge peak can vary among animals (typically, as previously indicated, at the 1600
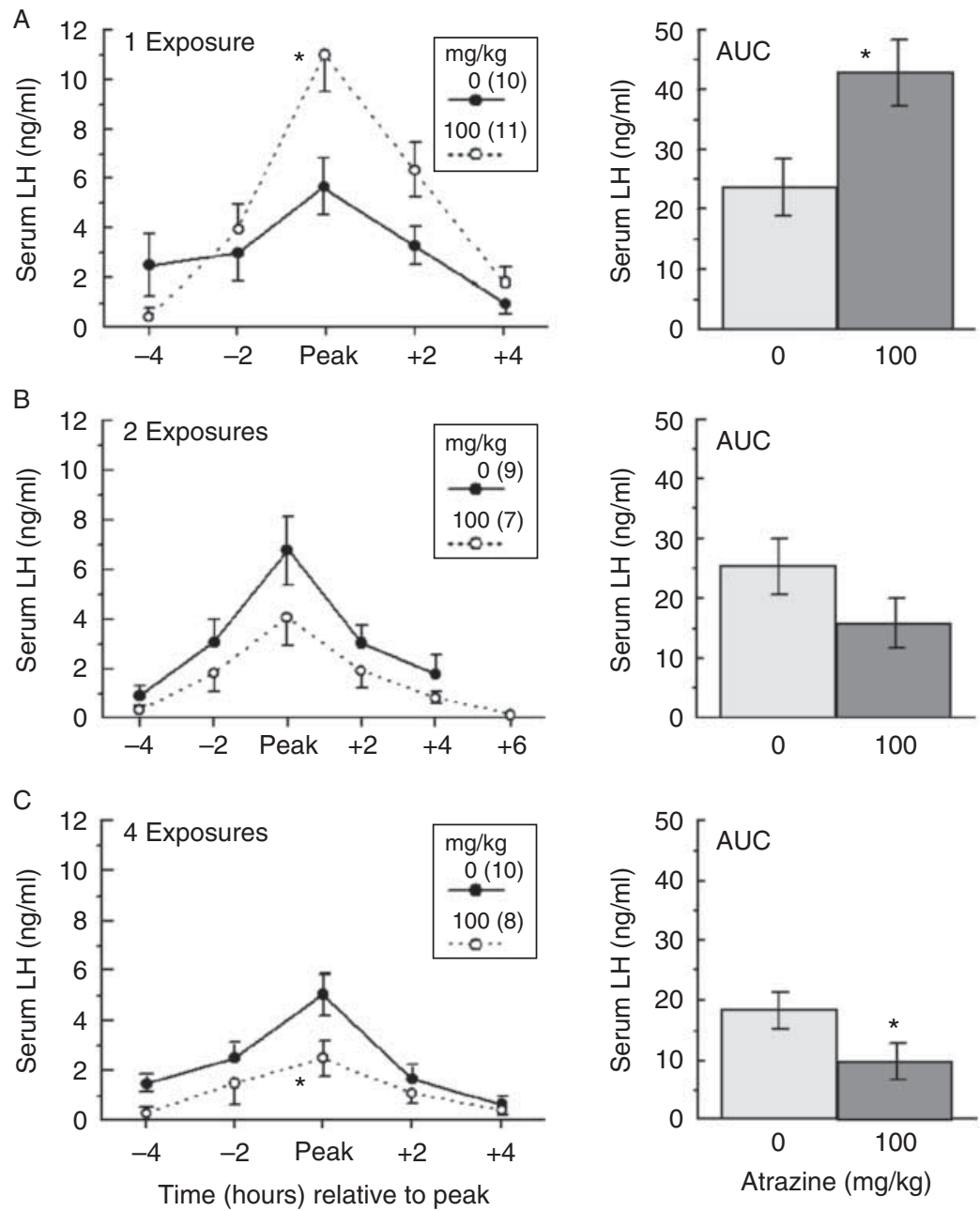

Figure 3 Effects of oral administration of 0 or $100 \mathrm{mg} / \mathrm{kg}$ ATRZ on the $\mathrm{LH}$ surge $(\mathrm{ng} / \mathrm{ml} \pm$ s.E.M.) following 1 (A), 2 (B), or $4(C)$ daily exposures in OVX, $E_{2}$-primed females. The left panels show plots of samples taken at $1400,1600,1800$, and $2000 \mathrm{~h}$. Values for individual animals within a dose group were shifted along the horizontal axis for a correspondence to the presence of the $\mathrm{LH}$ peak. The panels at right represent ATRZ effects on areas under the curve (AUC) for the one, two, and four daily treatments. The percentages of females in each group exhibiting a surge were $0 \mathrm{mg} / \mathrm{kg}-100 \%, 100 \mathrm{mg} / \mathrm{kg}-91 \%$ (one exposure); $0 \mathrm{mg} / \mathrm{kg}-100 \%, 100 \mathrm{mg} / \mathrm{kg}-88 \%$ (two exposures); and $0 \mathrm{mg} / \mathrm{kg}-100 \%, 100 \mathrm{mg} / \mathrm{kg}-80 \%$ (four exposures). For each of these days, the difference in percentage from controls was not statistically significant. Group sizes for those females with a surge are shown in parentheses. ${ }^{*} P<0.05$ for comparisons to $0 \mathrm{mg} / \mathrm{kg}$ controls at that sampling time. 
or $1800 \mathrm{~h}$ sampling times), the four $\mathrm{LH}$ values for each animal were shifted as a group along the horizontal axis so that analyses could be performed on the peaks (or highest $\mathrm{LH}$ concentrations), along with times designated as $-6,-4,-2$, +2 , +4 , and $+6 \mathrm{~h}$ from the peak. Common baseline concentrations were determined for each treatment group, and animals that failed to show at least a twofold peak elevation above baseline were eliminated from analyses of the surge. $\mathrm{E}_{2}$ and $\mathrm{P}_{4}$ concentrations in Experiment 1 were analyzed by Student's $t$-test, whereas those in Experiment 2 were assessed by the Kruskal-Wallis procedure followed by Dunn's multiple comparison test. The AUCs for the sampling times were determined using MedCalc Software (Mariakerke, Belgium) and then analyzed by $t$-test (Experiment 1) or ANOVA with Dunnett's test (Experiment 2). For the 4-day treatments in Experiment 2, differences among dose groups in the distribution of AUCs along the range of obtained values were evaluated by $\chi^{2}$ analysis. Statistical analyses of PCR data used $\Delta \mathrm{Cq}$ values, and graphed results indicate fold changes $\left(2^{-\Delta \Delta C q}\right)$ from controls (Livak \& Schmittgen 2001). Statistical significance for all analyses was set at $P \leq 0.05$.

\section{Results}

\section{Experiment 1}

Figure 2 shows the effect of $100 \mathrm{mg} / \mathrm{kg}$ ATRZ on serum $\mathrm{P}_{4}$ concentrations at $30 \mathrm{~min}$ and $1 \mathrm{~h}$ following one and four daily exposures. For the one-time exposure, there was a prompt eightfold elevation over controls that persisted over the course of $1 \mathrm{~h}$. At 4 days, the concentrations, while markedly elevated at $30 \mathrm{~min}$, decreased to near control levels by $1 \mathrm{~h}$. No differences between one and four daily treatments with ATRZ were present in circulating $E_{2}$ concentrations from $\mathrm{E}_{2}$ implants ( 1 day $-0 \mathrm{mg} / \mathrm{kg}$
$61.5 \pm 3.8 \mathrm{pg} / \mathrm{ml} ; 1$ day $-100 \mathrm{mg} / \mathrm{kg} 64.9 \pm 7.8 ; 4$ days $0 \mathrm{mg} / \mathrm{kg} 61.2 \pm 5.6 ; 4$ days $-100 \mathrm{mg} / \mathrm{kg} 72.7 \pm 5.3$ ).

In response to a single daily ATRZ treatment, there were significant elevations in $\mathrm{LH}$ present at the surge peak (Fig. 3A). When calculated as AUC, the effect on LH was statistically significant $(P \leq 0.05)$ at $181 \%$ of controls. Following 2 days of dosing, a statistical difference at the peak was no longer present (Fig. 3B), while the AUC, although not statistically significant, had fallen to $62 \%$ of controls, a marked drop from a single day of treatment. Serial samples taken after 4 days of treatment showed a significant decline in $\mathrm{LH}$ at the peak $(P \leq 0.05)$ compared with the vehicle controls (Fig. 3C). The decrease in AUC was statistically significant $(P \leq 0.05)$ at $54 \%$ of controls.

\section{Experiment 2}

Using the same paradigm employed in Experiment 1, dose-response assessments of $\mathrm{P}_{4}$ and $\mathrm{E}_{2}$ were conducted at $1 \mathrm{~h}$ following one and four daily exposures of ATRZ (Fig. 4). Following a single daily exposure, there was a dose-related increase in $\mathrm{P}_{4}$, with concentrations in the 30 and $100 \mathrm{mg} / \mathrm{kg}$ group statistically significant at $P<0.01$. No differences in circulating $E_{2}$ were present across the dose range. By the fourth day of dosing, no differences in serum $\mathrm{P}_{4}$ were present, with the lowered concentrations in the $100 \mathrm{mg} / \mathrm{kg}$ group consistent with effects seen in Experiment 1 (Fig. 2). Levels of $E_{2}$ were again comparable across dose groups.

For the single exposure to $100 \mathrm{mg} / \mathrm{kg}$, there was a significant increase at the LH peak along with post-peak elevations at 2 and $4 \mathrm{~h}$ (Fig. 5A). As in Experiment 1, the AUC was also increased at this dose (Fig. 5B).
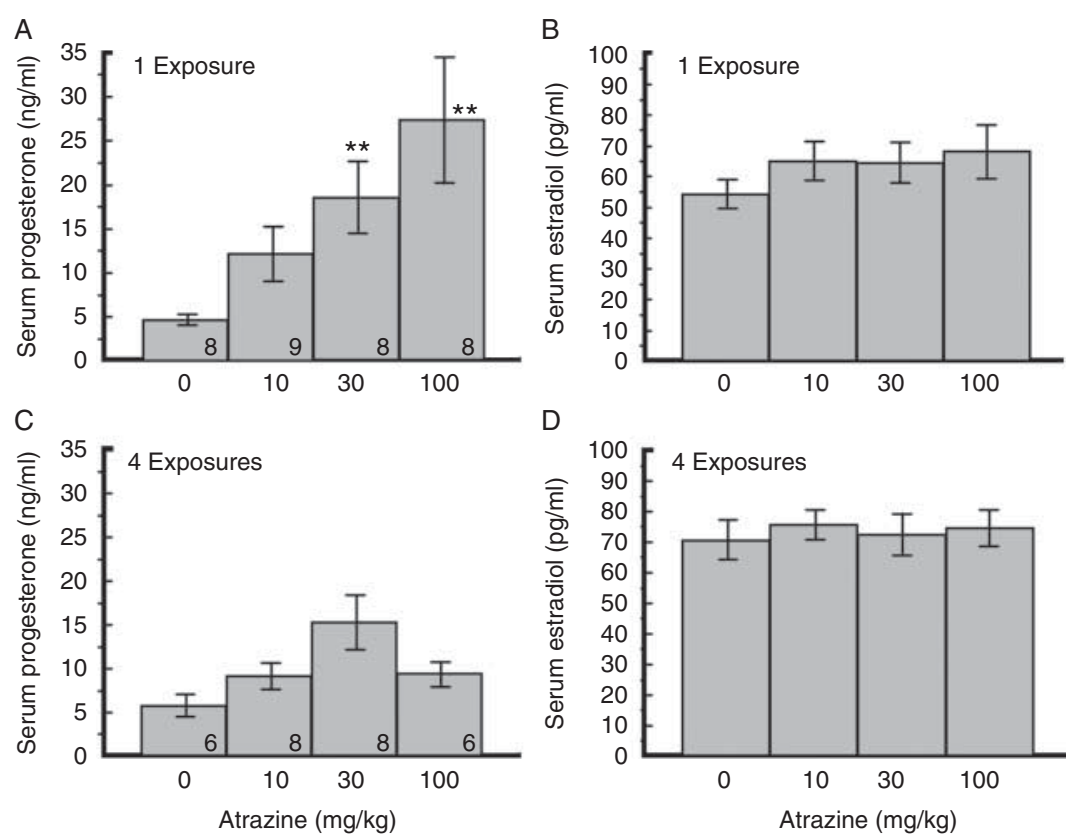

Figure 4 Serum concentrations ( \pm S.E.M.) at $1 \mathrm{~h}$ of $\mathrm{P}_{4}$ ( $A$ and $C$ ) and $E_{2}(B$ and $D)$ after 1 day or the last day of four daily treatments $(1300 \mathrm{~h}$ ) with $0,10,30$, or $100 \mathrm{mg} / \mathrm{kg}$ ATRZ. Group sizes are shown at the base of the $\mathrm{P}_{4}$ columns. ${ }^{* *} P<0.01$ for comparison to $0 \mathrm{mg} / \mathrm{kg}$ controls. 

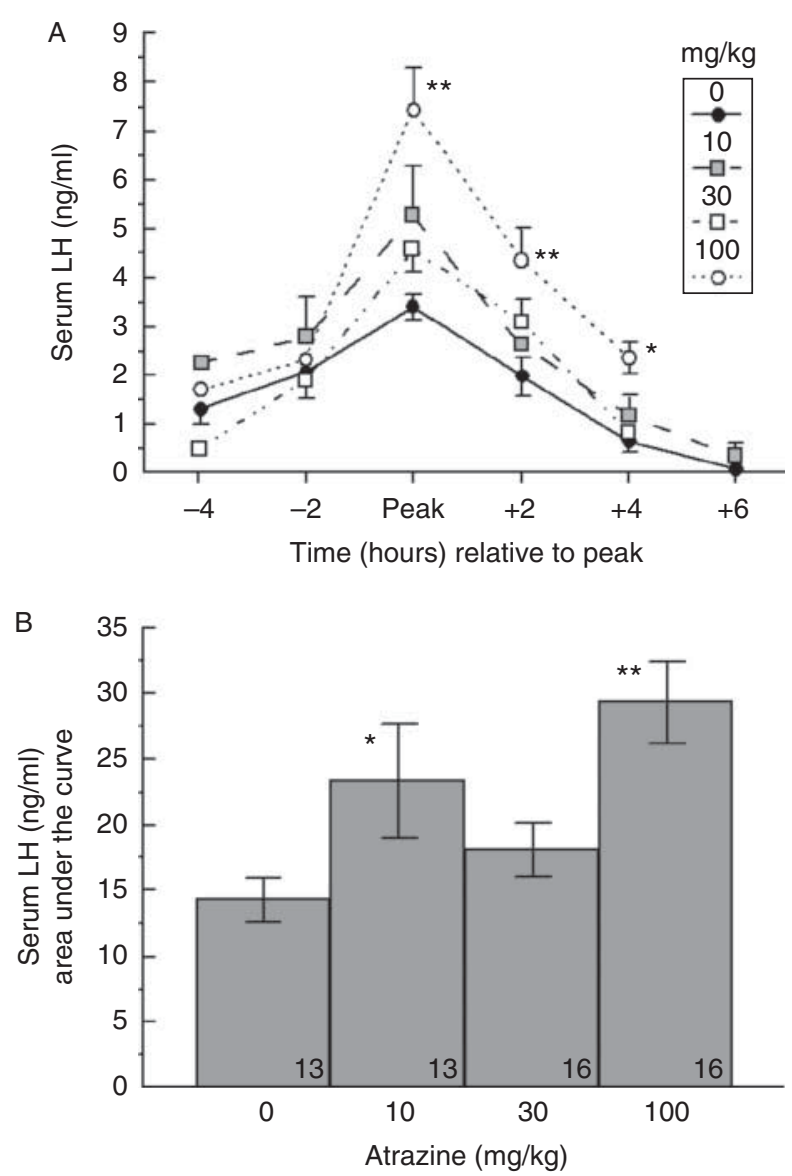

Figure $5 \mathrm{LH}$ surge $(\mathrm{ng} / \mathrm{ml} \pm$ s.E.M. $)$ following a single oral ATRZ dose of $0,10,30$, or $100 \mathrm{mg} / \mathrm{kg}$ in OVX, $E_{2}$-primed females (A).

Values for individual animals within a treatment group were shifted along the horizontal axis according to the presence of the LH peak. The percentages of females in each group exhibiting a surge were $0 \mathrm{mg} / \mathrm{kg}-93 \%, 10 \mathrm{mg} / \mathrm{kg}-87 \%, 30 \mathrm{mg} / \mathrm{kg}-100 \%$, and $100 \mathrm{mg} / \mathrm{kg}-100 \%$. The lower panel (B) indicates the AUC for these dose groups, with group sizes located at the base of each column. ${ }^{*} P<0.05$; ${ }^{* *} P<0.01$ for comparisons to $0 \mathrm{mg} / \mathrm{kg}$ controls at the corresponding time relative to the $\mathrm{LH}$ peak or to the control AUC.

However, even though $\mathrm{P}_{4}$ was found to be elevated at $30 \mathrm{mg} / \mathrm{kg}$, this dose did not have a corresponding effect on the surge. Following the four daily exposures, the apparent decline in the LH surge (Fig. 6A) and AUC (Fig. 6B) from control levels did not reach statistical significance.

In response to four daily ATRZ treatments, the lack of a significant reduction on the LH AUC in the $100 \mathrm{mg} / \mathrm{kg}$ group was investigated further by grouping the distribution of the AUC concentrations into segments along the range of obtained values (Fig. 7). It is evident that a few animals in this dose group did exhibit a sizable effect on LH even though $62.5 \%$ of females had AUCs below $10 \mathrm{ng} / \mathrm{ml}$, masking an overall decrease. In fact, five of the ten animals in this segment had values of $5 \mathrm{ng} / \mathrm{ml}$ or less. This is in contrast to control animals that showed $61.5 \%$ of AUCs falling between 10 and $20 \mathrm{ng} / \mathrm{ml}$. A $\chi^{2}$ analysis of the groups resulted in a probability of 0.057 , which although marginally beyond the 0.05 cutoff, is strongly suggestive of an effect and would be in agreement with the suppression reported in Experiment 1.

\section{Experiment 3}

A single exposure to $100 \mathrm{mg} / \mathrm{kg}$ ATRZ caused a 2.25-fold increase $(P<0.05)$ at $1 \mathrm{~h}$ in the expression of Kiss 1 (Fig. 8), whereas there was no difference from controls $1 \mathrm{~h}$ after four daily treatments at this dose. Consistent with data shown in Figs 1 and 3, $100 \mathrm{mg} / \mathrm{kg}$ caused a prompt and marked elevation in circulating $\mathrm{P}_{4}$ that fell to near control levels on the fourth day of treatment. Serum concentrations of $E_{2}$ from implanted capsules were also comparable across day and dose and were consistent with levels presented for Experiments 1 and 2.

\section{Discussion}

A number of previous studies (Cooper et al. 2000, McMullin et al. 2004, Foradori et al. 2009) demonstrated that daily ATRZ treatments administered over 3-5 consecutive days in steroid-primed, OVX rats caused a significant attenuation in the $\mathrm{LH}$ surge. However, this is the first report to show that a single dose of ATRZ will increase the amount of $\mathrm{LH}$ released if a female is exposed in the hours immediately preceding the expected rise in LH. This augmentation is in agreement with the synergistic relationship between $E_{2}$ and $P_{4}$ at this time and demonstrates that the increase in circulating $\mathrm{P}_{4}$ in response to an ATRZ-induced activation of the adrenal axis has a clear impact on the central regulation of $\mathrm{LH}$. As $\mathrm{E}_{2}$ concentrations are comparable across the dose groups, there does not appear to be an effect of treatment on $\mathrm{E}_{2}$ clearance or metabolism.

In the cycling rat, there are multiple sites of $\mathrm{P}_{4}$ production independent of the ovaries. Adrenal secretion occurs in concentrations that are typically comparable to ovarian release (Fajer et al. 1971, Shaikh \& Shaikh 1975). There is also evidence that local $P_{4}$ synthesis is present in hypothalamic astrocytes and has been shown to occur in response to estrogen feedback (Micevych et al. 2003), linking this effect to generation of the LH surge. However, under the present paradigm, the large and prompt ATRZ-induced elevation in circulating $\mathrm{P}_{4}$ implicates adrenal $\mathrm{P}_{4}$ as a principal driving factor in the $\mathrm{LH}$ results observed. It then becomes clear that in a cycling female, the herbicide is able to affect $\mathrm{P}_{4}$ secretion from both ovaries and adrenals. By themselves, the ovaries will secrete significant amounts of $\mathrm{P}_{4}$ in response to ATRZ. It had previously been shown that cultures of granulosa cells treated with ATRZ in vitro responded with an increase in $\mathrm{P}_{4}$ (Tinfo et al. 2011). In addition, data from our laboratory (J M Goldman, L K Davis and A S Murr, unpublished observations) have demonstrated that 4 days of ATRZ exposure to immature female rats treated with pregnant mare serum gonadotropin caused 

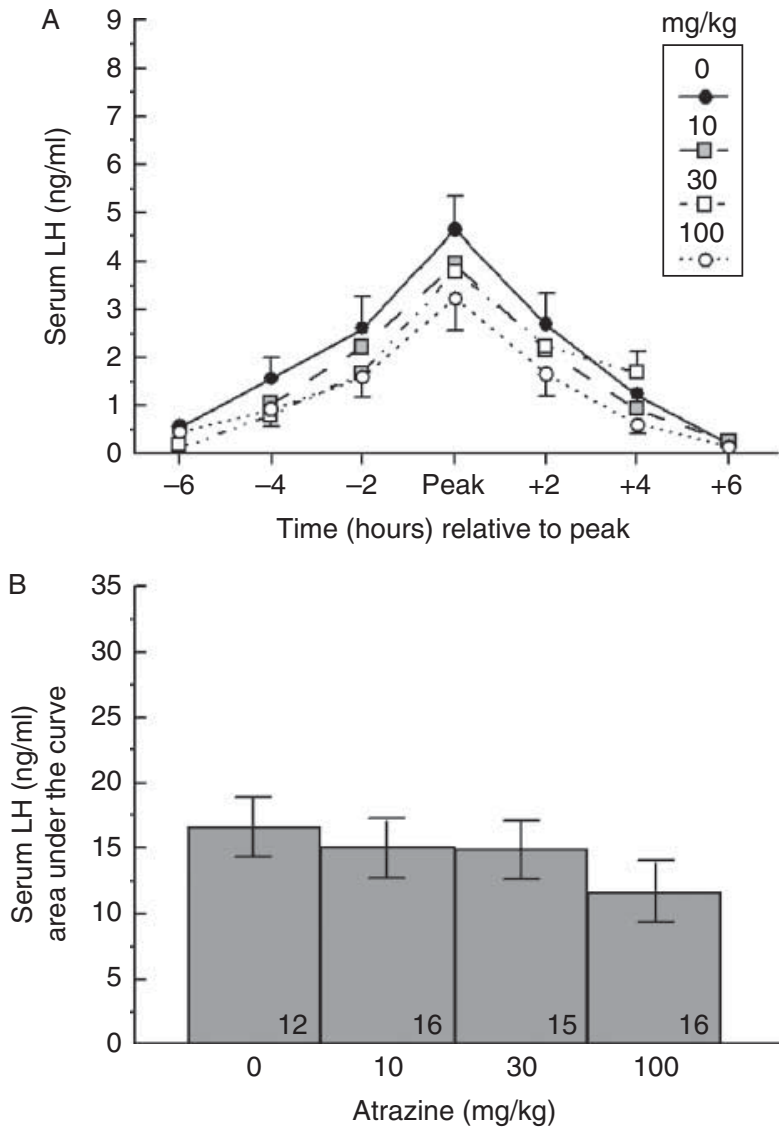

Figure $6 \mathrm{LH}$ surge $(\mathrm{ng} / \mathrm{ml} \pm$ s.E.M.) following four daily oral treatments with $0,10,30$, or $100 \mathrm{mg} / \mathrm{kg}$ in OVX, $\mathrm{E}_{2}$-primed females (A). Values for individual animals within a treatment group were shifted along the horizontal axis according to the presence of the LH peak. The percentages of females in each group exhibiting a surge were $0 \mathrm{mg} / \mathrm{kg}-88 \%, 10 \mathrm{mg} / \mathrm{kg}-100 \%, 30 \mathrm{mg} / \mathrm{kg}-100 \%$, and $100 \mathrm{mg} / \mathrm{kg}-93 \%$. The lower panel (B) indicates the AUC for these dose groups, with group sizes located at the base of each column.

marked dose-related elevations in $\mathrm{P}_{4}$ from excised preovulatory follicles maintained in culture.

The results reported by Fraites et al. (2009) showed that just $15 \mathrm{~min}$ after a single oral $75 \mathrm{mg} / \mathrm{kg}$ exposure in intact rats, ATRZ was able to induce a rapid spike in $\mathrm{P}_{4}$ to $\sim 19 \mathrm{ng} / \mathrm{ml}$, a concentration that was greater than fourfold over controls. At $15 \mathrm{~min}$ after the last of four daily ATRZ doses, Fraites et al. found that the mean $\mathrm{P}_{4}$ concentration was $7 \mathrm{ng} / \mathrm{ml}$, markedly lower than the 1-day value, suggesting a decline in the $\mathrm{P}_{4}$ response with multiple exposures. Although the present data did not show a significant decline in the $\mathrm{P}_{4}$ response to $100 \mathrm{mg} / \mathrm{kg}$ at $30 \mathrm{~min}$ between the one and four daily exposures, there was an evident attenuation between them at $1 \mathrm{~h}$, with values for the 4-day group at this dose approximating control levels in all experiments.

The dramatic decline in $\mathrm{P}_{4}$ between 30 min and $1 \mathrm{~h}$ for the 4-day treatment may be attributable to a combined effect of the decrease with multiple ATRZ exposures in the duration of adrenal $\mathrm{P}_{4}$ secretion coupled with a rapid clearance, as the mean half-life for $\mathrm{P}_{4}$ in OVX rats has been reported to be a bit $<3$ min (Pepe \& Rothchild 1973). Even though this treatment-induced elevation in $\mathrm{P}_{4}$ is present over an abbreviated interval of time, $\mathrm{P}_{4}$ administration under $E_{2}$ priming has been shown to cause a large elevation at 30 min in hypothalamic protein kinase C (PKC) activity (Balasubramanian et al. 2008). This effect is initiated at the plasma membrane and is non-genomic. Such an increase in PKC, moreover, was able to induce a rapid rise in secretion from immortalized GnRH neurons in culture that was followed at 16 h by a decline in $\mathrm{GnRH}$ mRNA (Wetsel et al. 1993).

The biphasic influence of $\mathrm{P}_{4}$ requires the participation of $E_{2}$ at both the hypothalamic and pituitary levels. Rising $\mathrm{E}_{2}$ concentrations during the cycle, or in response to an $\mathrm{E}_{2}$ prime in OVX females, induce an increase in the number of $\mathrm{P}_{4}$ receptors at both sites (Roselli \& Snipes 1983, Camp \& Barraclough 1985, Turgeon et al. 1999), augmenting the influence of elevated $\mathrm{P}_{4}$ just prior to the surge. In the days subsequent to a short-term $\mathrm{P}_{4}$ treatment, or in response to continued exposure, $\mathrm{P}_{4}$ will then downregulate its own receptors, leading to an attenuation of the LH surge (Barraclough et al. 1986, Turgeon \& Waring 2000). In fact, in cycling animals, it is this post-ovulatory rise in luteal $\mathrm{P}_{4}$ (present for a short time during the typical rodent cycle or for a more extended period during pregnancy) that prevents the

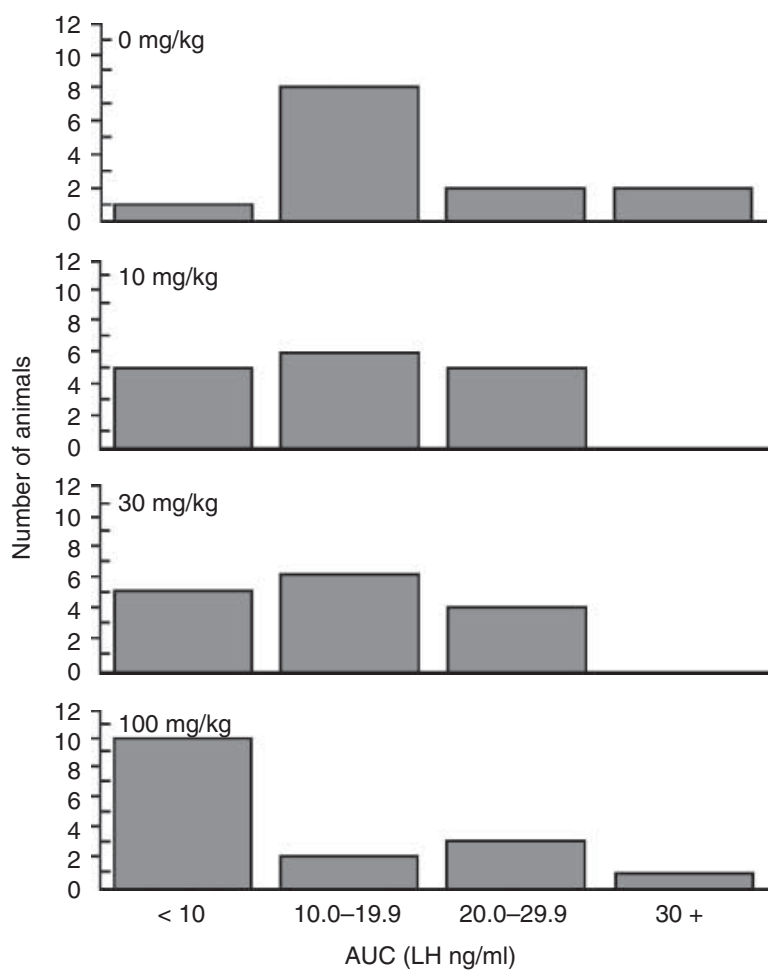

Figure 7 Areas under the curve for the four daily treatments separated into the number of animals within each treatment group falling within segments along the range of obtained AUC values. A $\chi^{2}$ analysis indicated a probability for a significant shift along that range of $P=0.057$. 


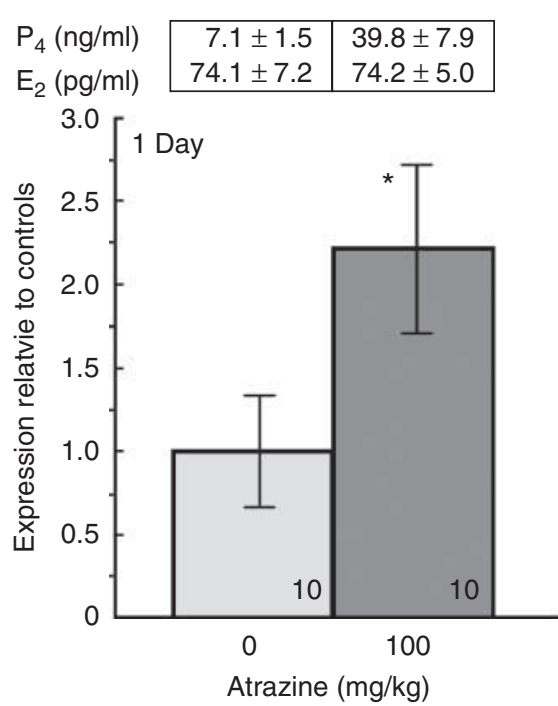

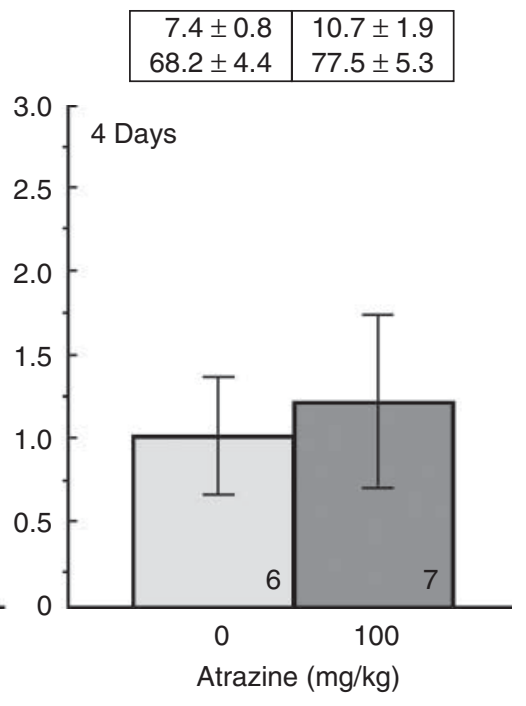

Figure 8 The expression of AVPV Kiss1 ( \pm s.E.M.) $1 \mathrm{~h}$ after a single-day ATRZ exposure $(100 \mathrm{mg} / \mathrm{kg}$ ) or the last day of four daily treatments at this dose. Results are normalized relative to controls as described in Livak \& Schmittgen (2001). Serum concentrations of $\mathrm{P}_{4}(\mathrm{ng} / \mathrm{ml})$ and $\mathrm{E}_{2}(\mathrm{pg} / \mathrm{ml})$ are located above each column, and group sizes are indicated at the column base. ${ }^{*} P<0.05$ compared to controls for that day. prompt re-appearance of the LH surge (Banks \& Freeman 1978), something that is seen daily in OVX rats exposed to $E_{2}$ only. We are not aware of any study evaluating the effect of ATRZ on hypothalamic or pituitary $\mathrm{P}_{4}$ receptors. However, it is of interest that Tennant et al. (1994) reported that 2-day treatments with ATRZ, simazine, or the common metabolite diaminochlorotriazine significantly diminished $\mathrm{P}_{4}$ receptor binding capacity in cytosol fractions prepared from uteri of OVX rats pretreated subcutaneously with $1 \mu \mathrm{g} \mathrm{E}_{2}$.

Using OVX rats, there are dose-related differences among previously published studies and the present one in the effectiveness of multiple ATRZ exposures on the LH surge. However, the significant LH suppression by lower dosages found by McMullin et al. (2004) and Foradori et al. (2009) may well be attributable to the fact that these studies employed priming with both $\mathrm{E}_{2}$ and $\mathrm{P}_{4}$. This injection of $\mathrm{P}_{4}$ would then add to the succession of ATRZ-induced $\mathrm{P}_{4}$ elevations, resulting in a lowering of the smallest effective dosage.

In cycling females, an ATRZ-induced elevation in $\mathrm{P}_{4}$ would likely have an impact on the cycle, at least in the short term. Although a single high dose of ATRZ given on the day of proestrus did not attenuate the LH surge and affect ovulation, multiple exposures beginning on diestrus day 1 were able to block the appearance of vaginal proestrus and suppress ovulation (Cooper et al. 2000). Moreover, in rats treated daily for 4 weeks with $40 \mathrm{mg} / \mathrm{kg}$ and above (Eldridge et al. 1999), there was a statistically significant increase in the number of days spent in diestrus, an effect consistent with the response to a previous elevation in circulating levels of $\mathrm{P}_{4}$.

In women, the contraceptive effects of exogenous sex steroids have been known for years, and a number of newer progestin-only oral contraceptives have been described to impact both the hypothalamus and pituitary (e.g. Faundes et al. 1991, Couzinet et al. 1999).
However, it is still an open question whether ATRZ, via an effect on $\mathrm{P}_{4}$, is able to adversely affect a woman's cycle. More recently, a preliminary epidemiological report indicated menstrual irregularities in women within a geographic region of extensive ATRZ usage compared with an area where the usage is much more limited (Cragin et al. 2011). The follicular phase was found to be lengthened, although there did not appear to be an association during this phase with urinary levels of the $\mathrm{P}_{4}$ metabolite pregnanediol 3-glucuronide (Pd3G). In contrast, luteal phase Pd3G was reduced, suggesting that long-term ATRZ exposures resulted in insufficient $\mathrm{P}_{4}$ secretion during this portion of the cycle. Such a decrease, at least outwardly, seems consistent with the previously indicated attenuation in $\mathrm{P}_{4}$ following multiple days of ATRZ treatment reported by Fraites et al. (2009) and with the current differences in $\mathrm{P}_{4}$ at $1 \mathrm{~h}$ (in all of the present Experiments) between single and four daily exposures in response to the $100 \mathrm{mg} / \mathrm{kg}$ treatment.

The elevation in expression of the Kiss 1 gene suggests that the increase in the surge at 1 day in response to ATRZ involves an impact of kisspeptin on $\mathrm{GnRH}$ secretion. Kisspeptin neurons are known to possess both $E_{2}$ and $P_{4}$ receptors (Clarkson et al. 2008, Clarke 2011), and AVPV membrane $P_{4}$ signaling molecules are believed to mediate rapid non-genomic responses to $\mathrm{E}_{2}+\mathrm{P}_{4}$ (Intlekofer \& Petersen 2011). The lack of a change in expression following four daily ATRZ exposures also suggests a possible receptor downregulation, along with an involvement of other neuroendocrine factors influencing the LH AUC at this time.

In response to ATRZ, there is an increase in circulating levels of $\mathrm{ACTH}$, which consequently triggers a marked secretion of corticosterone from the adrenals (Laws et al. 2009). Previous studies have indicated that elevated corticosterone concentrations could suppress the surge under a variety of conditions (Kam et al. 2000, 
Fraites et al. 2009, Laws et al. 2009). However, this does not appear likely for a single ATRZ exposure. Employing the same OVX, $E_{2}$-primed model in a study of the pesticide chlordimeform, our laboratory demonstrated that the administration of a single dose of corticosterone in the hours prior to the surge did not alter $\mathrm{LH}$ secretion (Goldman et al. 1991). The resulting serum concentrations of corticosterone in that study approximated those reported by Fraites et al. (2009) following a single $75 \mathrm{mg} / \mathrm{kg}$ ATRZ treatment. These findings would argue against the possibility that a single morning ATRZ-stimulated rise in corticosterone would modify the afternoon surge in this model. However, if the same dose of corticosterone was given on the day prior to the expected LH surge, there was a significant suppression in the mean peak concentration (Goldman et al. 1991). Thus, combined with the present $\mathrm{P}_{4}$ data, these observations indicate that the effect of repeated ATRZ treatments may well reflect a collective action of both these adrenocortical steroids.

In summary, the results of this study demonstrate for the first time that there is a bidirectional shift in the effect of ATRZ on the LH surge, which is consistent with the temporal influence of a treatment-related elevation in $\mathrm{P}_{4}$. In helping to define a mode of action, these observations also suggest that the activation of the hypothalamicpituitary-adrenal axis plays a significant role in the toxicity pathway associated with the ATRZ-induced disruption in LH regulation. The extent to which the observations in this acute study are pertinent to the interference of pituitary-ovarian function following a chronic exposure, however, remains to be determined.

\section{Declaration of interest}

The authors declare that there is no conflict of interest that could be perceived as prejudicing the impartiality of the research reported.

\section{Funding}

The research described in this manuscript was conducted entirely with funds provided internally by the US Environmental Protection Agency.

\section{Acknowledgements}

The authors wish to thank Al Moore and Ann-Marie Brandt (Priority One Services) for their assistance in dosing, providing animal husbandry support, and obtaining daily vaginal lavages. The contributions of Angela Buckalew, Deborah Best, Nicola Evans, Curtis Grace (US EPA), and Hunter Sampson (N.C. State Univ./ORISE student intern) in obtaining serial samples for hormonal analyses are also greatly appreciated. The research described in this article has been reviewed by the National Health and Environmental Effects Research Laboratory, US Environmental Protection Agency and approved for publication. Approval does not signify that the contents necessarily reflect the views and policies of the Agency nor does mention of trade names or commercial products constitute endorsement or recommendation for use.

\section{References}

Balasubramanian B, Portillo W, Reyna A, Chen JZ, Moore AN, Dash PK \& Mani SK 2008 Nonclassical mechanisms of progesterone action in the brain: I. Protein kinase $\mathrm{C}$ activation in the hypothalamus of female rats. Endocrinology 149 5509-5517. (doi:10.1210/en.2008-0712)

Banks JA \& Freeman ME 1978 The temporal requirement of progesterone on proestrus for extinction of the estrogen-induced daily signal controlling luteinizing hormone release in the rat. Endocrinology 102 426-432. (doi:10.1210/endo-102-2-426)

Barraclough CA, Camp P, Weiland N \& Akabori A 1986 Stimulatory versus inhibitory effects of progesterone on estrogen-induced phasic $\mathrm{LH}$ and prolactin secretion correlated with estrogen nuclear and progestin cytosol receptor concentrations in brain and pituitary gland. Neuroendocrinology 42 6-14. (doi:10.1159/000124241)

Caligaris L, Astrada JJ \& Taleisnik S 1971 Biphasic effect of progesterone on the release of gonadotropin in rats. Endocrinology 89 331-337. (doi:10.1210/endo-89-2-331)

Camp P \& Barraclough CA 1985 Correlation of luteinizing hormone surges with estrogen nuclear and progestin cytosol receptors in the hypothalamus and pituitary gland. Neuroendocrinology 40 45-53. (doi:10.1159/000124050)

Clarke IJ 2011 Control of GnRH secretion: one step back. Frontiers in Neuroendocrinology 32 367-375. (doi:10.1016/j.yfrne.2011.01.001)

Clarkson J, d'Anglemont de Tassigny X, Moreno AS, Colledge WH \& Herbison AE 2008 Kisspeptin-GPR54 signaling is essential for preovulatory gonadotropin-releasing hormone neuron activation and the luteinizing hormone surge. Journal of Neuroscience 28 8691-8697. (doi:10.1523/JNEUROSCI.1775-08.2008)

Cooper RL, Stoker TE, Goldman JM, Parrish MB \& Tyrey L 1996 Effect of atrazine on ovarian function in the rat. Reproductive Toxicology $\mathbf{1 0}$ 257-264. (doi:10.1016/0890-6238(96)00054-8)

Cooper RL, Stoker TE, Tyrey L, Goldman JM \& McElroy WK 2000 Atrazine disrupts the hypothalamic control of pituitary-ovarian function. Toxicological Sciences 53 297-307. (doi:10.1093/toxsci/53.2.297)

Cooper RL, Laws SC, Das PC, Narotsky MG, Goldman JM, Tyrey EL \& Stoker TE 2007 Atrazine and reproductive function: mode and mechanism of action studies. Birth Defects Research. Part B: Developmental and Reproductive Toxicology 80 98-112. (doi:10.1002/bdrb.20110)

Couzinet B, Young J, Kujas M, Meduri G, Brailly S, Thomas JL, Chanson P \& Schaison G 1999 The antigonadotropic activity of a 19-nor-progesterone derivative is exerted both at the hypothalamic and pituitary levels in women. Journal of Clinical Endocrinology and Metabolism $\mathbf{8 4}$ 4191-4196. (doi:10.1210/jc.84.11.4191)

Cragin LA, Kesner JS, Bachand AM, Barr DB, Meadows JW, Krieg EF \& Reif JS 2011 Menstrual cycle characteristics and reproductive hormone levels in women exposed to atrazine in the drinking water. Environmental Research 111 1293-1301. (doi:10.1016/j.envres.2011.09.009)

DePaolo LV \& Barraclough CA 1979 Dose dependent effects of progesterone on the facilitation and inhibition of spontaneous gonadotropin surges in estrogen treated ovariectomized rats. Biology of Reproduction 21 1015-1023. (doi:10.1095/biolreprod21.4.1015)

Eldridge JC, Wetzel LT \& Tyrey L 1999 Estrous cycle patterns of SpragueDawley rats during acute and chronic atrazine administration. Reproductive Toxicology 13 491-499. (doi:10.1016/S0890-6238(99)00056-8)

Everett JW \& Sawyer CH 1950 A 24-hour periodicity in the "LH-release apparatus" of female rats, disclosed by barbiturate sedation. Endocrinology 47 198-218. (doi:10.1210/endo-47-3-198)

Fajer AB, Holzbauer M \& Newport HM 1971 The contribution of the adrenal gland to the total amount of progesterone produced in the female rat. Journal of Physiology 214 115-126.

Faundes A, Brache V, Tejada AS, Cochon L \& Alvarez-Sanchez F 1991 Ovulatory dysfunction during continuous administration of low-dose levonorgestrel by subdermal implants. Fertility and Sterility 56 27-31.

Foradori CD, Hinds LR, Hanneman WH \& Handa RJ 2009 Effects of atrazine and its withdrawal on gonadotropin-releasing hormone neuroendocrine function in the adult female Wistar rat. Biology of Reproduction 81 1099-1105. (doi:10.1095/biolreprod.109.077453) 
Fraites MJ, Cooper RL, Buckalew A, Jayaraman S, Mills L \& Laws SC 2009 Characterization of the hypothalamic-pituitary-adrenal axis response to atrazine and metabolites in the female rat. Toxicological Sciences $\mathbf{1 1 2}$ 88-99. (doi:10.1093/toxsci/kfp194)

Friedmann AS 2002 Atrazine inhibition of testosterone production in rat males following peripubertal exposure. Reproductive Toxicology $\mathbf{1 6}$ 275-279. (doi:10.1016/S0890-6238(02)00019-9)

Goldman JM, Cooper RL, Edwards TL, Rehnberg GL, McElroy WK \& Hein JF 1991 Suppression of the luteinizing hormone surge by chlordimeform in ovariectomized, steroid-primed female rats. Pharmacology \& Toxicology 68 131-136. (doi:10.1111/j.1600-0773.1991.tb02050.x)

Goldman JM, Murr AS \& Cooper RL 2007 The rodent estrous cycle: characterization of vaginal cytology and its utility in toxicological studies. Birth Defects Research. Part B, Developmental and Reproductive Toxicology 80 84-97. (doi:10.1002/bdrb.20106)

Goldman JM, Murr AS, Buckalew AR \& Cooper RL 2008 Suppression of the steroid-primed luteinizing hormone surge in the female rat by sodium dimethyldithiocarbamate: relationship to hypothalamic catecholamines and GnRH neuronal activation. Toxicological Sciences 104 107-112. (doi:10.1093/toxsci/kfn074)

Gottsch ML, Cunningham MJ, Smith JT, Popa SM, Acohido BV, Crowley WF, Seminara S, Clifton DK \& Steiner RA 2004 A role for kisspeptins in the regulation of gonadotropin secretion in the mouse. Endocrinology 145 4073-4077. (doi:10.1210/en.2004-0431)

Greig F \& Weisz J 1973 Preovulatory levels of luteinizing hormone, the critical period and ovulation in rats. Journal of Endocrinology $\mathbf{5 7}$ 235-245. (doi:10.1677/joe.0.0570235)

Gysin H \& Knuesli E 1960 Chemistry and herbicidal properties of triazine derivatives. In Advances in Pest Control Research, vol 3, pp 289-358. Ed R Metcalf. New York: Wiley Interscience.

Intlekofer KA \& Petersen SL 2011 17 $\beta$-Estradiol and progesterone regulate multiple progestin signaling molecules in the anteroventral periventricular nucleus, ventromedial nucleus and sexually dimorphic nucleus of the preoptic area in female rats. Neuroscience 176 86-92. (doi:10.1016/j.neuroscience.2010.12.033)

Kam K, Park Y, Cheon M, Son GH, Kim K \& Ryu K 2000 Effects of immobilization stress on estrogen-induced surges of luteinizing hormone and prolactin in ovariectomized rats. Endocrine 12 279-287. (doi:10.1385/ENDO:12:3:279)

Laws SC, Hotchkiss M, Ferrell J, Jayaraman S, Mills L, Modic W, Tinfo N, Fraites M, Stoker T \& Cooper R 2009 Chlorotriazine herbicides and metabolites activate an ACTH-dependent release of corticosterone in male Wistar rats. Toxicological Sciences 112 78-87. (doi:10.1093/toxsci/ kfp190)

Legan SJ \& Karsch FJ 1975 A daily signal for the LH surge in the rat. Endocrinology 96 57-62. (doi:10.1210/endo-96-1-57)

Legan SJ, Coon GA \& Karsch FJ 1975 Role of estrogen as initiator of daily LH surges in the ovariectomized rat. Endocrinology 96 50-56. (doi:10.1210/ endo-96-1-50)

Livak KJ \& Schmittgen TD 2001 Analysis of relative gene expression data using real-time quantitative PCR and the 2 (-Delta Delta $C(\mathrm{~T}))$ method. Methods 25 402-408. (doi:10.1006/meth.2001.1262)

Mahesh VB \& Muldoon TG 1987 Integration of the effects of estradiol and progesterone in the modulation of gonadotropin secretion. Journal of Steroid Biochemistry 27 665-675. (doi:10.1016/0022-4731(87)90135-X)

McMullin TS, Andersen ME, Nagahara A, Lund TD, Pak T, Handa RJ \& Hanneman WH 2004 Evidence that atrazine and diaminochlorotriazine inhibit the estrogen/progesterone induced surge of luteinizing hormone in female Sprague-Dawley rats without changing estrogen receptor action. Toxicological Sciences 79 278-286. (doi:10.1093/toxsci/kfh127)

Micevych P, Sinchak K, Mills RH, Tao L, LaPolt P \& Lu JKH 2003 The luteinizing hormone surge is preceded by an estrogen-induced increase of hypothalamic progesterone in ovariectomized and adrenalectomized rats. Neuroendocrinology 78 29-35. (doi:10.1159/000071703)

Navarro VM, Castellano JM, Fernández-Fernández R, Tovar S, Roa J, Mayen A, Nogueiras R, Vazquez MJ, Barreiro ML, Magni P et al. 2005 Characterization of the potent luteinizing hormone-releasing activity of KiSS-1 peptide, the natural ligand of GPR54. Endocrinology 146 156-163. (doi:10.1210/en.2004-0836)
Pepe GJ \& Rothchild I 1973 Metabolic clearance rate of progesterone: comparison between ovariectomized, pregnant, pseudopregnant and deciduoma-bearing pseudopregnant rats. Endocrinology 93 1200-1205. (doi:10.1210/endo-93-5-1200)

Pogrmic K, Fa S, Dakic V, Kaiserevic S \& Kovacevic R 2009 Atrazine oral exposure of peripubertal male rats downregulates steroidogenesis gene expression in Leydig cells. Toxicological Sciences 111 189-197. (doi:10.1093/toxsci/kfp135)

Pogrmic-Majkic K, Fa S, Dakic V, Kaisarevic S \& Kovacevic R 2010 Upregulation of peripubertal rat Leydig cell steroidogenesis following $24 \mathrm{~h}$ in vitro and in vivo exposure to atrazine. Toxicological Sciences 118 52-60. (doi:10.1093/toxsci/kfq227)

Rivest P, Devine PJ \& Sanderson JT 2010 Evaluation of a bioluminescent mouse model expressing aromatase PII-promoter-controlled luciferase as a tool for the study of endocrine disrupting chemicals. Toxicology and Applied Pharmacology 249 33-40. (doi:10.1016/j.taap.2010.08.011)

Roselli CE \& Snipes CA 1983 Cytoplasmic progesterone receptors in the hypothalamus-preoptic area of the mouse: effect of estrogen priming. Journal of Steroid Biochemistry 19 1571-1575. (doi:10.1016/00224731(83)90372-2)

Sanderson JT, Seinen W, Giesy JP \& van den Berg M 2000 2-Chloro-striazine herbicides induce aromatase (CYP19) activity in H295R human adrenocortical carcinoma cells: a novel mechanism for estrogenicity? Toxicological Sciences 54 121-127. (doi:10.1093/toxsci/54.1.121)

Shaikh AA \& Shaikh SA 1975 Adrenal and ovarian steroid secretion in the rat estrous cycle temporally related to gonadotropins and steroid levels found in peripheral plasma. Endocrinology 96 37-44. (doi:10.1210/ endo-96-1-37)

Taketa Y, Yoshida M, Inoue K, Takahashi M, Sakamoto Y, Watanabe G, Taya K, Yamate J \& Nishikawa A 2011 Differential stimulation pathways of progesterone secretion from newly formed corpora lutea in rats treated with ethylene glycol monomethyl ether, sulpiride, or atrazine. Toxicological Sciences 121 267-278. (doi:10.1093/toxsci/kfr062)

Tennant MK, Hill DS, Eldridge JC, Wetzel LT, Breckenridge CB \& Stevens JT 1994 Possible antiestrogenic properties of chloro-s-triazines in rat uterus. Journal of Toxicology and Environmental Health 43 183-196. (doi:10.1080/15287399409531914)

Tinfo NS, Hotchkiss MG, Buckalew AR, Zorrilla LM, Cooper RL \& Laws SC 2011 Understanding the effects of atrazine on steroidogenesis in rat granulosa and $\mathrm{H} 295 \mathrm{R}$ adrenal cortical carcinoma cells. Reproductive Toxicology 31 184-193. (doi:10.1016/j.reprotox.2010.11.005)

Trentacoste SV, Friemann AS, Youker RT, Breckenridge CB \& Zirkin BR 2001 Atrazine effects on testosterone levels and androgen-dependent reproductive organs in peripubertal male rats. Journal of Andrology 22 $142-148$.

Turgeon JL \& Waring DW 2000 Progesterone regulation of the progesterone receptor in rat gonadotropes. Endocrinology 141 3422-3429. (doi:10.1210/en.141.9.3422)

Turgeon JL, Van Patten SM, Shyamala G \& Waring DW 1999 Steroid regulation of progesterone receptor expression in cultured rat gonadotropes. Endocrinology 140 2318-2325. (doi:10.1210/en.140.5.2318)

Victor-Costa AB, Bandeira SMC, Oliveira AG, Mahecha GAB \& Oliveira CA 2010 Changes in testicular morphology and steriodogenesis in adult rats exposed to atrazine. Reproductive Toxicology 29 323-331. (doi:10.1016/j.reprotox.2009.12.006)

Wetzel LT, Luempert LG III, Breckenridge CB, Tisdel MO, Stevens JT, Thakur AK, Extrom PJ \& Eldridge JC 1994 Chronic effects of atrazine on estrus and mammary tumor formation in female Sprague-Dawley and Fischer 344 rats. Journal of Toxicology and Environmental Health $\mathbf{4 3}$ 169-182. (doi:10.1080/15287399409531913)

Wetsel WC, Eraly SA, Whyte DB \& Mellon PL 1993 Regulation of gonadotropin-releasing hormone by protein kinase-A and $-C$ in immortalized hypothalamic neurons. Endocrinology 132 2360-2370. (doi:10.1210/en.132.6.2360)

Received 14 January 2013

First decision 25 March 2013

Revised manuscript received 30 May 2013

Accepted 11 July 2013 